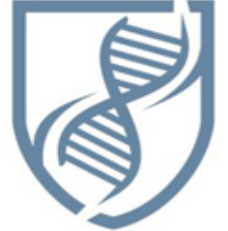

Journal of Bioscience and Applied Research
JBAAR

WWW.JBAAR.ORG

\title{
Anti-oxidant and Anti-inflammatory activity of Tabebuia rosea (Flowers)
}

\author{
S.Solomon ${ }^{1}$ M.M.Senthamilselvi ${ }^{2}$ N.Muruganantham ${ }^{3}$
}

1. Department of Chemistry, Periyar E.V.R.College, Tiruhirappallli, Tamil Nadu, India.

2. Regional Joint Director, Department of Higher Education, Tiruchirappalli, Tamil Nadu, India. 3. Department of Chemistry, Roever Engineering College, Perambalur, Tamil Nadu, India

( Corresponding author email:solomon.simonchem@gmail.com)

\begin{abstract}
The aim of this study is to investigate the antiinflammatory and anti-oxidant activities of the sample isolated from the ethyl acetate fraction of flowers of Tabebuia rosea. Anti-inflammatory activity of the sample was determined by HRBC membrane stabilization and Albumin denaturation methods. Anti-oxidant activity of the sample was determined by DPPH assay and ABTS method. The results of the study suggest that the sample isolated from the ethyl acetate fraction possesses anti-oxidant and anti-inflammatory activity.
\end{abstract}

Keywords: Antioxidant activity, Anti-inflammatory activity, Albumin denaturation, ABTS assay, DPPH, HRBC method, Tabebuia rosea 1

\section{Introduction}

Inflammation is a general term for a pathophysiological process characterized by fever, redness, edema and pain (Kim et al., 2004). It is a part of a nonspecific immune response to noxious stimuli, trauma and infection (Calixto et al., 2004) and results in vasodilatation, increased blood flow, elevated cellular metabolism, release of soluble mediators, extravasation of fluids and cellular influx (Ferrero-Miliani et al., 2007). Prolonged inflammation is implicated in the onset and progression of various pathologies including cardiovascular diseases and cancer (Vendramini-Costa et al., 2012). 'Anti-inflammatory agent' is a drug that inhibits any facet of inflammation of an experimentally induced nature or as a part of clinical syndrome (Smith et al., 1966).

Tabebuia rosea (bertol) D.C, belong to the family bignoniaceae commonly known as pink trumpet Tree, grow upto 15 meters and well known for its beautiful flowers. Tea made from the leaves and bark is known to have a fever reducing effect. The herbal products obtained from the bark of tabebuia trees are called Taheebo, lapacho, pandarco and iperoxo. Traditionally, it has been used for treating ulcers, syphilis, gastrointestinal problems, Cancer, diabetics, prostatitis, constipation and allergies (Hemamalini et al., 2014).

\section{Materials and Methods}

\subsubsection{Collection of Flowers}

Fresh flowers of Tabebuia rosea were collected from Jail Corner, Tiruchirappalli, Tamil Nadu, India, during the month of May and identified by Dr.S.John Britto, Director, The rapinat Herbarium and Centre for Molecular Systematics (Authentication No. SS002 dated: 06/11/2015). St.Joseph's College (Campus), Tiruchirappalli, Tamil Nadu, India.

\subsubsection{Extraction and fractionation}

Fresh flowers (3 kg) of Tabebuia rosea were extracted with $90 \%$ ethanol $(5 \times 500 \mathrm{ml})$. The combined alcoholic extract was concentrated in vacuo and the aqueous extract was successively fractionated with petroleum ether $\left(60-80^{\circ} \mathrm{C}\right)(6 \mathrm{x} 250 \mathrm{ml})$, Peroxide free diethyl ether $(4 \times 250 \mathrm{ml})$ and ethyl acetate $(8 \times 250 \mathrm{ml})$. Petroleum ether fraction and diethyl ether fraction did not yield any isolable material. Ethyl acetate fraction on concentration yielded a dry powder which was dissolved in DMSO to get various concentrations and were used for further study.

\subsection{IN VITRO ANTIOXIDANT ACTIVITY}

\subsubsection{DPPH Assay Method}

The DPPH free radical is reduced to a corresponding hydrazine when it reacts with hydrogen 
donors. The DPPH radical is purple in colour and upon reaction with hydrogen donor changes to yellow colour. It is a decolouration assay, which is evaluated by the addition of the antioxidant to a DPPH solution in ethanol or methanol and the decrease in absorbance was measured at 490nm (Solomon et al., 2015).

\subsubsection{Reagents:}

2.2.2.1 2,2-Diphenyl 1-picryl hydrazyl solution (DPPH, $100 \mu \mathrm{mol} / \mathrm{L})$ :

$22 \mathrm{mg}$ of DPPH was accurately weighed and dissolved in $100 \mathrm{ml}$ of methanol. From this stock solution, $18 \mathrm{ml}$ was taken and diluted to $100 \mathrm{ml}$ using methanol to obtain $100 \mu \mathrm{mol} / \mathrm{L}$ DPPH solution.

2.2.2.2 Preparation of test solutions:

$21 \mathrm{mg}$ of the solid obtained from ethyl acetate fraction was dissolved in distilled DMSO to obtain a solution of $21 \mathrm{mg} / \mathrm{ml}$ concentration. This solution was serially diluted to obtain lower concentrations.

2.2.2.3 Preparation of standard solutions:

$10 \mathrm{mg}$ each of ascorbic acid and rutin were weighed separately and dissolved in $1 \mathrm{ml}$ of Dimethyl sulfoxide (DMSO) to get $10 \mathrm{mg} / \mathrm{ml}$ concentrations. These solutions were serially diluted with DMSO to get lower concentrations.

\subsubsection{Procedure:}

The assay was carried out in a 96 well microtitre plate. To $200 \mu \mathrm{l}$ of DPPH solution, $10 \mu \mathrm{l}$ of each of the test sample or the standard solution was added separately in wells of the microtitre plate. The final concentration of the test and standard solutions used were 1000, 500, 125 and $31.25 \mu \mathrm{mol} / \mathrm{L}$. The plates were incubated at $37^{\circ} \mathrm{C}$ for 30 min and the absorbance of each solution was measured at $490 \mathrm{~nm}$, using a micro plate reader.

\subsection{EVALUATION OF TOTAL ANTIOXIDANT CAP ACITY OF THE EXTRACT}

The total antioxidant capacity was determined by phosphomolybdenum method and is based on the reduction of Mo (VI) to Mo (V) by the antioxidant compounds and the formation of a green Mo (V) complex which has the maximal absorption at $695 \mathrm{~nm}$.

\subsubsection{Preparation of test and standard solutions}

Weighed accurately 55mg of the sample and the standard, ascorbic acid and dissolved in $5 \mathrm{ml}$ of DMSO. The lower dilutions were made serially with DMSO.

\subsubsection{Procedure}

An aliquot of $0.1 \mathrm{ml}$ of the sample solution containing a reducing species in DMSO was combined in an Eppendorff tube with $1 \mathrm{ml}$ of reagent solution $(0.6 \mathrm{mM}$ Sulphuric acid, $28 \mu \mathrm{mol} / \mathrm{L}$ sodium phosphate, and $4 \mathrm{mM}$ ammonium molybdate). The tubes were capped and incubated in water bath at $95^{\circ} \mathrm{C}$ for $90 \mathrm{~min}$. The samples were cooled to room temperature, and the absorbance of each solution was measured at $695 \mathrm{~nm}$. The total antioxidant capacity was expressed as $\mu \mathrm{mol} / \mathrm{L}$ equivalent of ascorbic acid.
Total antioxidant activity $=343.8 \mu \mathrm{mol} / \mathrm{L}$

\subsection{ABTS radical scavenging activity:}

ABTS radical scavenging activity was performed with a slight modification. $7.0 \mathrm{mM}$ ABTS in $14.7 \mathrm{mM}$ ammonium peroxo-disulphate was prepared in $5.0 \mathrm{ml}$ distilled water. The mixture was allowed to stand at room temperature for 24 hours. The resulting blue green ABTS radical solution was further diluted such that its absorbance is $0.70 \pm 0.020$ at $734 \mathrm{~nm}$. Various concentrations of the sample solution (in ethanol) $(20.0 \mu \mathrm{l})$ were added to 980.0 $\mu \mathrm{l}$ of ABTS radical solution and the mixture was incubated in darkness for $10 \mathrm{~min}$. The decrease in absorbance was read at $734 \mathrm{~nm}$. A test tube containing $20.0 \mu \mathrm{l}$ of ethanol processed as described above was served as the control tube. Different concentrations of ascorbic acid were used as reference compound.

\subsection{ANTI- INFLAMMATORY ACTIVITY}

\subsubsection{The human red blood cell (HRBC) membrane} stabilization method

The method as prescribed was adopted with some modifications. The blood was collected from healthy human volunteer who had not taken any NSAIDS for 2 weeks prior to the experiment and mixed with equal volume of Alsever solution (2\% dextrose, $0.8 \%$ sodium citrate, $0.5 \%$ citric acid and $0.42 \% \mathrm{NaCl}$ ) and centrifuged at 3,000 rpm. The packed cells were washed with isosaline and a $10 \%$ suspension was made. Various concentrations of test drug were prepared in $\mathrm{mg} / \mathrm{ml}$ using distilled water and to each concentration, $1 \mathrm{ml}$ of phosphate buffer, $2 \mathrm{ml}$ hypo saline and $0.5 \mathrm{ml}$ of HRBC suspension were added. It was incubated at $37^{0} \mathrm{C}$ for 30 minutes and centrifuged at 3,000 rpm for 20 minutes and the hemoglobin content of the supernatant solution was estimated spectrophotometrically at $560 \mathrm{~nm}$. Diclofenac $(100 \mathrm{Jg} / \mathrm{ml})$ was used as reference standard and a control was prepared by omitting the test drug. The experiments were performed in triplicates and mean values of the three were considered. The percentage (\%) of HRBC membrane stabilization or protection was calculated (Solomon et al., 2015),

\section{Percentage of Protection (\%) =}

\section{(100- OD of drug treated sample/OD of Control) X 100} 2.5.2 Albumin denaturation method

The method as prescribed was followed with some modifications. The reaction mixture was consisting of test sample and $1 \%$ solution of bovine albumin fraction. $\mathrm{pH}$ of the reaction mixture was adjusted using small amount of $\mathrm{HCl}$. The mixtures were incubated at $37^{\circ} \mathrm{C}$ for 20 minutes and then heated to $51^{\circ} \mathrm{C}$ for 20 minutes. After cooling the samples the turbidity was measured spectrophotometrically at $660 \mathrm{~nm}$. Diclofenac sodium was taken as a standard drug. The experiment was performed in triplicates and the mean value of the three was considered. Percent inhibition of protein denaturation was calculated as follows (Solomon et al., 2015),

Percentage of inhibition $(\%)=$ (OD of Control- OD of Sample/ OD of Control) X 1004. 


\section{Results and Discussion}

\subsection{Anti-oxidant activity:}

The compound Kaempferol 3-O-(2"'- $\alpha$-methyl pcoumaryl)- $\beta$-d-glucoside(Senthamilselvi et al., 2016) isolated from the ethyl acetate fractions of Tabebuia rosea flowers exhibited significant anti-oxidant activity when compared with DPPH assay. It is evident from the data presented in Table-I that the sample possessed DPPH assay activity. The result showed the percentage of cytotoxicity for $1000 \mu \mathrm{g} / \mathrm{ml}$ as $67.03 \%, 500 \mu \mathrm{g} / \mathrm{ml}$ as $65.42 \%, 125$ $\mu \mathrm{g} / \mathrm{ml} 53.18 \%$, and for $31.25 \mu \mathrm{g} / \mathrm{ml} 44.85 \%$. When compared with ABTS assay activity, it is evident from the data presented in Table II that the sample possesses ABTS assay activity. The result showed the percentage of cytotoxicity for $1000 \mu \mathrm{g} / \mathrm{ml}$ as $65.41 \%, 500 \mu \mathrm{g} / \mathrm{ml}$ as $58.26 \%, 125 \mu \mathrm{g} / \mathrm{ml}$ as $49.12 \%$, and for $31.25 \mu \mathrm{g} / \mathrm{ml}$ as $40.23 \%$. Total antioxidant activity of the sample is 343.8 $\mu \mathrm{g} / \mathrm{ml}$.

\subsection{Anti-inflammatory activity:}

The compound Kaempferol 3-O-(2"'- $\alpha$-methyl pcoumaryl)- $\beta$-d-glucoside isolated from the ethyl acetate fractions of Tabebuia rosea flowers exhibited significant anti-inflammatory activity of the human red blood cell (HBRC) membrane stabilization and the results are presented in Table III. The result showed the percentage of inhibition in membrane stabilization for $100 \mu \mathrm{g} / \mathrm{ml}$ as
$34.99 \pm 0.17 \%, 200 \mu \mathrm{g} / \mathrm{ml}$ as $39.21 \pm 0.52 \%, 400 \mu \mathrm{g} / \mathrm{ml}$ as $45.03 \pm 1.73 \%, 600 \mu \mathrm{g} / \mathrm{ml}$ as $57.89 \pm 1.86 \%$, and for $600 \mu \mathrm{g} / \mathrm{ml}$ as $69.12 \pm 1.34 \%$. The inhibition of Albumin denaturation activity exhibited by the compound are given in Table IV. The results showed the percentage of inhibition in membrane stabilization for $100 \mu \mathrm{g} / \mathrm{ml}$ as 35.08 $\pm 0.17 \%, 200 \mu \mathrm{g} / \mathrm{ml}$ as $40.13 \pm 0.25 \%, 300 \mu \mathrm{g} / \mathrm{ml}$ as $48.26 \pm 0.73 \%, 600 \mu \mathrm{g} / \mathrm{ml}$ as $59.92 \pm 0.39 \%$, and for 800 $\mu \mathrm{g} / \mathrm{ml}$ as $69.78 \pm 0.14$.The anti-inflammatory effect of the compound isolated from ethyl acetate fraction(test sample) of Tabebuia rosea may be due to presence of active constituent flavonoids. The results strongly suggest antiinflammatory effects and anti-oxidant effects by percentage of inhibitions, which are explained in the Table 1,2,3,4.

\section{Conclusion}

The present study has confirmed that both DPPH assay and ABTS have showed a strong antioxidant activity and also the human red blood cell (HRBC) membrane stabilization. It could be concluded that the compound isolated from the ethyl acetate fraction of flowers of Tabebuia rosea of phytopharmaceutical importance. However, isolation of individual phytochemical constituents and subjecting it to biological testing will definitely give fruitful results.

Table No. 1 : DPPH assay activity of the compound isolated from the ethyl acetate fraction of flowers of Tabebuia rosea

\begin{tabular}{|c|c|c|c|c|}
\hline S. No & $\begin{array}{c}\text { Concentration } \\
(\mu \mathrm{mol} / \mathrm{L})\end{array}$ & $\begin{array}{l}\text { Ascorbic acid } \\
\text { (Standard) }\end{array}$ & $\begin{array}{c}\text { \% CTC } \text { CT0 }_{50} \\
\text { Cytotoxicity } \\
\text { (umol/L) }\end{array}$ & $\begin{array}{c}\mathrm{IC}_{50} \\
(\boldsymbol{\mu m o l} / \mathrm{L})\end{array}$ \\
\hline 1 & 1000 & 80.64 & 67.03 & \multirow{4}{*}{104.23} \\
\hline 2 & 500 & 68.17 & 65.42 & \\
\hline 3 & 125 & 55.54 & 53.18 & \\
\hline 4 & 31.25 & 44.26 & 44.85 & \\
\hline
\end{tabular}

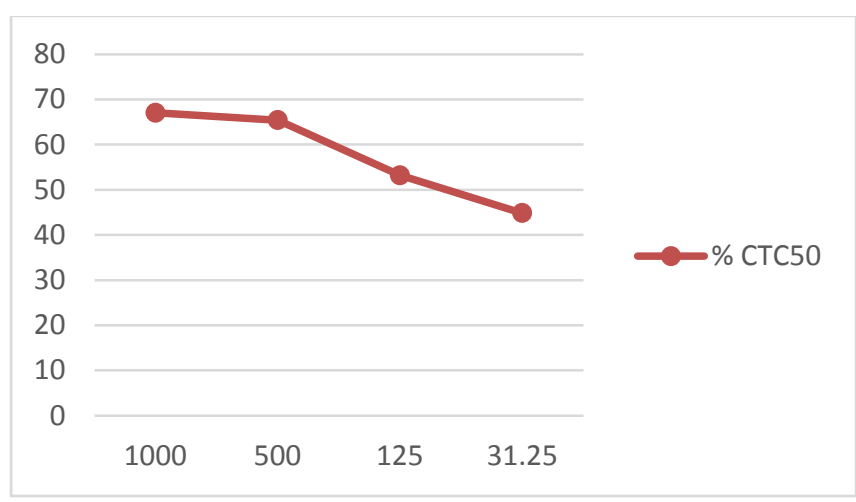


Table No. 2 : ABTS assay activity of the compound isolated from the ethyl acetate fraction of flowers of Tabebuia rosea

\begin{tabular}{|c|c|c|c|c|}
\hline S. No & $\begin{array}{c}\text { Concentration } \\
(\boldsymbol{\mu m o l} / \mathbf{L})\end{array}$ & $\begin{array}{c}\text { Ascorbic acid } \\
\text { (Standard) }\end{array}$ & $\begin{array}{c}\text { \% } \mathbf{C T C}_{\mathbf{5 0}} \\
\mathbf{C y t o t o x i c i t y} \\
(\boldsymbol{\mu m o l} / \mathbf{L})\end{array}$ & $\begin{array}{c}\text { IC }_{\mathbf{5 0}} \\
(\boldsymbol{\mu m o l} / \mathbf{L})\end{array}$ \\
\hline 1 & 1000 & 86.15 & 65.41 & \multirow{2}{*}{150.30} \\
\hline 2 & 500 & 69.55 & 58.26 & \\
\hline 3 & 125 & 58.97 & 49.12 & \\
\hline
\end{tabular}

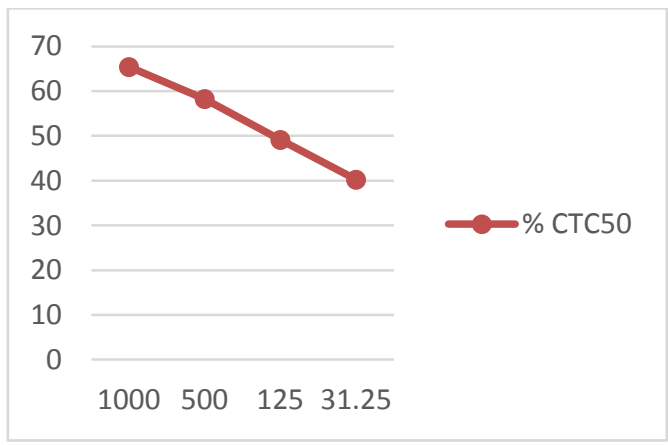

Graph No.2: Graphical representation of ABTS radical scavenging activity of the compound isolated from the ethyl acetate fraction of flowers of Tabebuia rosea.

Table 3: The human red blood cell (HRBC) membrane Stabilization activity of the compound isolated from the ethyl acetate fraction of flowers of Tabebuia rosea

\begin{tabular}{|c|c|c|c|}
\hline \multirow{2}{*}{ S. No } & $\begin{array}{c}\text { Concentration } \\
(\boldsymbol{\mu m o l} / \mathbf{L})\end{array}$ & $\begin{array}{c}\text { Diclofenac sodium } \\
\text { (Standard) }\end{array}$ & \begin{tabular}{c} 
\% of Inhibition \\
\cline { 3 - 3 }
\end{tabular} \\
\hline 1 & 100 & $49.18 \pm 0.18$ & $34.99 \pm 0.17$ \\
\hline 2 & 200 & $56.29 \pm 0.35$ & $39.21 \pm 0.52$ \\
\hline 3 & 400 & $65.84 \pm 0.26$ & $45.03 \pm 1.73$ \\
\hline 4 & 600 & $70.75 \pm 0.18$ & $57.89 \pm 1.86$ \\
\hline 5 & 800 & $78.20 \pm 0.84$ & $69.12 \pm 1.34$ \\
\hline
\end{tabular}

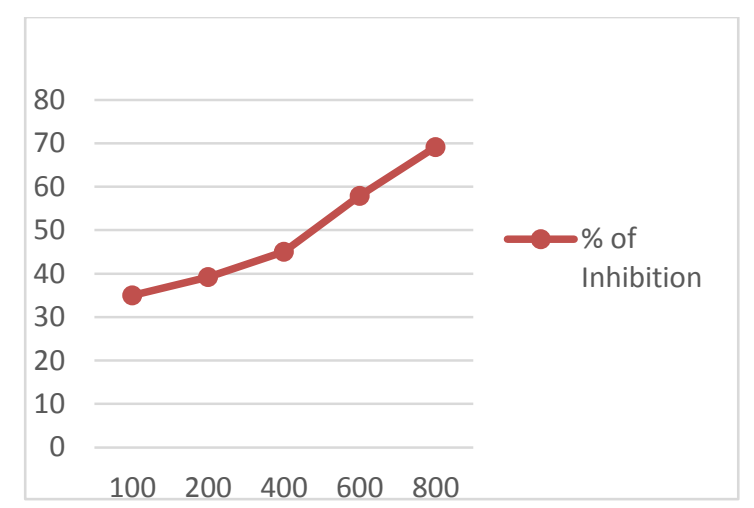

Graph 3: Graphical representation of human red blood cell (HRBC) membrane Stabilization activity of the compound isolated from the ethyl acetate fraction of flowers of Tabebuia rosea 
Table 4: The Inhibition of Albumin Denaturation activity of the compound isolated from the ethyl acetate fraction of flowers of Tabebuia rosea

\begin{tabular}{|c|c|c|c|}
\hline S. No & $\begin{array}{c}\text { Concentration } \\
\text { ( } \boldsymbol{\mu m o l} / \mathbf{L})\end{array}$ & $\begin{array}{c}\text { Diclofenac sodium } \\
\text { (Standard) }\end{array}$ & $\begin{array}{c}\text { Membrane Stabilization } \\
\text { Mean } \pm \text { S.E.M }\end{array}$ \\
\hline 1 & 100 & $52.18 \pm 0.03$ & $35.08 \pm 0.17$ \\
\hline 2 & 200 & $60.72 \pm 0.16$ & $40.13 \pm 0.25$ \\
\hline 3 & 400 & $69.84 \pm 0.29$ & $48.26 \pm 0.73$ \\
\hline 4 & 600 & $75.19 \pm 0.94$ & $59.92 \pm 0.39$ \\
\hline 5 & 800 & $86.09 \pm 1.85$ & $69.78 \pm 0.14$ \\
\hline
\end{tabular}

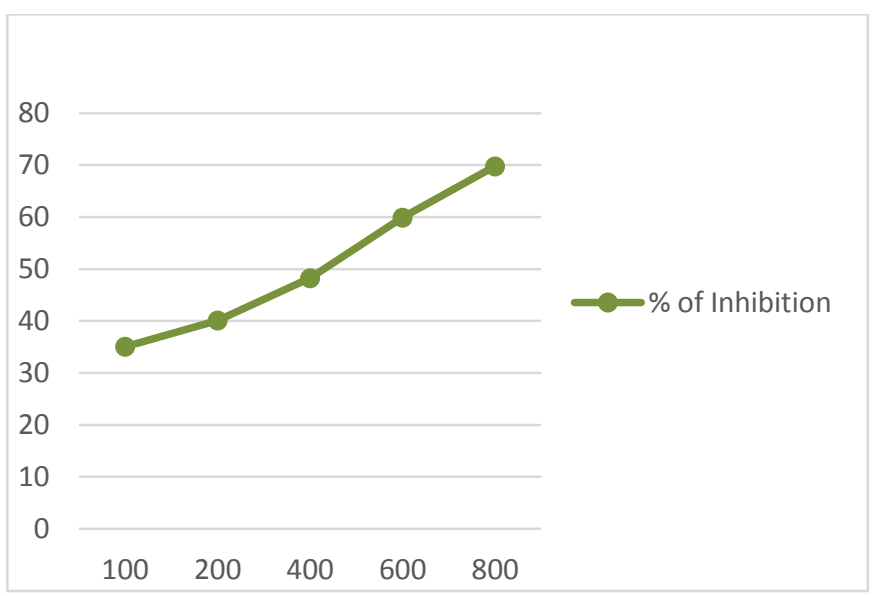

Graph 4: Graphical representation of Inhibition of Albumin Denaturation activity of the compound isolated from the ethyl acetate fraction of flowers of Tabebuia rosea

\section{References}

Calixto JB, Campos MM, Otuki MF, Santos AR (2004) Anti-inflammatory compounds of plant origin. Part II. Modulation of proinflammatory cytokines, chemokines and adhesion molecules. Planta Med. 70: 93-103.

Ferrero-Miliani L, Nielsen OH, Andersen PS, Girardin SE (2007) Chronic inflammation: importance of NOD2 and NALP3 in interleukin- 1beta generation. Clin Exp Immunol. 147: 227-235.

Hemamalini K, Sambasiva rao A, (2014) Anti ulcerogenic models of Sophora interrupta Solanum pubescens and Tabebuia rosea leaves on In-vivo test model in rats. Int J Pharm Pharm Sci. 6(6): 520.

Kim HP, Son KH, Chang HW, Kang SS (2004) Anti-inflammatory plant flavonoids and cellular action mechanisms. J Pharmacol Sci. 96: 229-245.

Senthamilselvi MM, Solomon S and Muruganantham N (2016) Isolation and characterization of Kaempferol 3-O-(2'"- $\alpha$-methyl p-coumaryl)- $\beta$-d-glucoside from Tabebuia rosea (Flowers). Am. J. Pharm Tech Res. 6(4), 223-231.

Smith MJH, (1966) in 'Salicylates', Smith MJH and Smith RK, Eds., Wiley-Intersciences, New York, p-49.

Solomon S, Muruganantham N and Senthamilselvi MM (2015) Anti-oxidant and anti-Inflammatory activity of Thespesia populnea (flowers). Pharmacophore (An International Research Journal). 6 (1), 53-59.

Vendramini-Costa DB, Carvalho JE (2012) Molecular link mechanisms between inflammation and cancer. Curr Pharm Des. 18: 3831-3852. 